
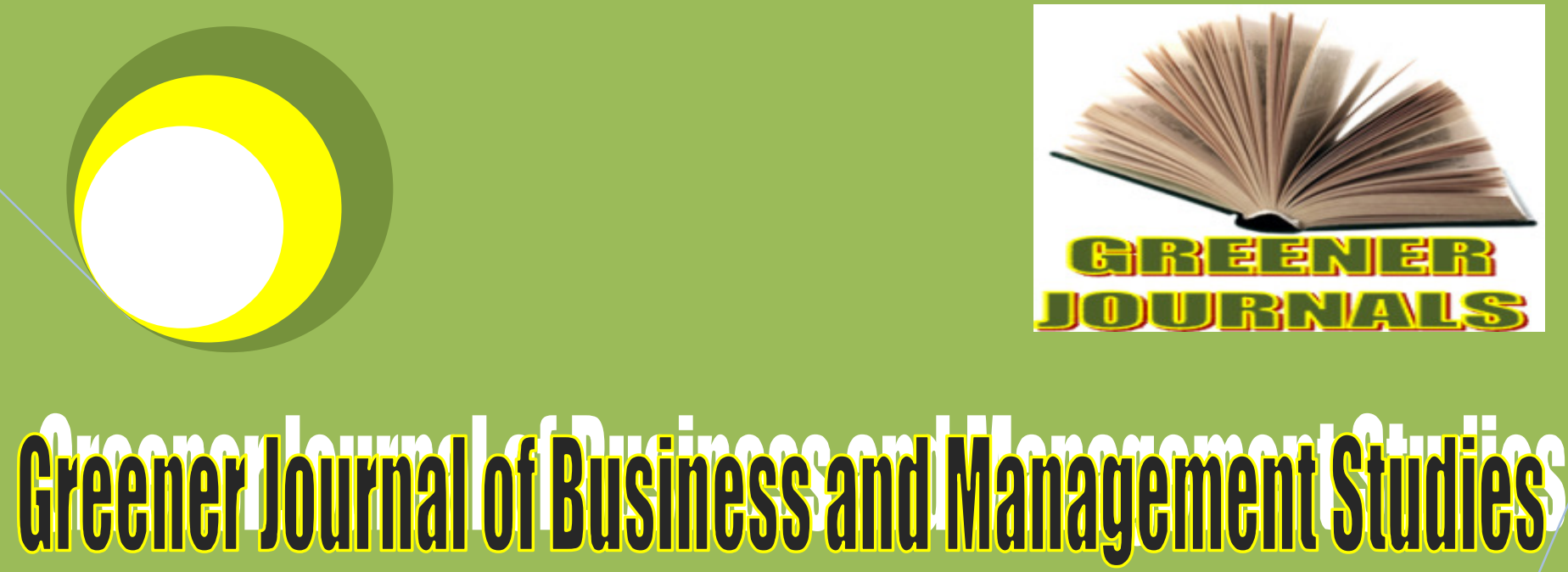

ISSN: 2276-7827 Impact Factor 2012 (UJRI): 0.6670 ICV 2012: 6.03

Leadership Styles in Church

Administration: A Case of the Seventh-Day Adventist Church Ghana

By

Samuel Kanyandekwe Irene Akuamoah Boateng 


\title{
Leadership Styles in Church Administration: A Case of the Seventh-Day Adventist Church - Ghana
}

\section{*Samuel Kanyandekwe and Irene Akuamoah Boateng}

\author{
Valley View University, School of Business, Ghana. \\ *Corresponding Author's Email: Ohenewah80@yahooco.uk
}

\begin{abstract}
The success of a leader depends critically not only on his abilities and skills but also on his own behavior, that is, various actions he takes to influence followers towards the attainment of organizational objectives. It is mandatory on him to create and maintain good work climate in compliance with organizational culture and to the satisfaction of employees.According to Jon and Dan (2006), many of us have known poor leaders who promote their own image by taking credit for work done by others, selfish, inconsiderate, or tyrannical with followers, or who are unfair, dishonest, and threatened by competence of people. There have been allegations that some men and women of God in church leadership positions do not offer enough to create good work environment in our conferences, missions, hospital, schools and other SDA (Seventh - day Adventist) church institutions. This study seeks to identify the leadership styles practiced by the Seventh-day Adventist Church Leaders.A descriptive survey was used to conduct the study. This design was used considering the nature of the study as a qualitative study and all employees and officers in SDA Conferences and Mission, schools, hospitals, church districts and some selected workers from ADRA(Adventist Relief Agency) constituted the target population. The convenience sampling technique was used to select the respondents. The study revealed that a cumulative percent of $\mathbf{8 4 . 7 0}$ of the respondents agreed that leaders in the church and church institutions exhibit leaders' reward/punishment strategies than all the other leadership styles. This was followed by laissez faire leadership style with a cumulative percentage of 76.06 of the respondents agreeing to that fact. Charismatic, directive and participative leadership styles follow in downward succession. Supportive and servant leadership styles happened to be the least leadership styles exhibited by these leaders. A cumulative percentage of 62.28 of the respondents agreed that their leaders have good work relationship with them. It is recommended that SDA Church Leaders need to reduce domineering attitude and cleaving to power. They should also practice more servant leadership and improve work relations.
\end{abstract}

Keywords: Leadership styles, Church administration, Leadership, Organizational goals.

\section{INTRODUCTION}

Leadership is defined as the process through which an individual influences the behaviors of followers in order to achieve organizational goals. The followers should see that influence on them as legitimate either through election or a position in the organizational structure. This understanding of the concept of a leadership assigns a pivotal role to a leader in an organization giving him various powers to be able to fulfill his responsibility to lead others (followers or employees) towards the achievement of stated goals(any type of the organization or church institutions).

The success of the leader depends critically not only on his abilities, skills but also on his own behaviors that is, various actions he takes to influence followers towards the attainment of organizational goals. It is incumbent on him to create and maintain good work climate in compliance with organizational culture and to the satisfaction of employees. This sounds like an ideal situation because most of the time many workers suffer at the hands of their leaders because little effort is made to build work environment which is conducive to the betterment of the lives of the employees who invest so much energy and efforts to get things done.

According to Jon and Dan (2006), many of us have known poor leaders who promote their own image by taking credit for work done by others, who are selfish, inconsiderate, or tyrannical with followers, or who are unfair, dishonest, and threatened by competence in other people. These factors decrease our quality of life lowering our job and life satisfaction and our commitment to organizations, while creating high levels of conflict and stress. The same writers continue saying that one recent survey indicated that over 75 percent of U.S. employees are unhappy with their jobs. The primary reason given was that they were treated poorly by their bosses. If this kind of situation is happening in one of the most leading countries in democracy with supposedly very high values in human rights, we 
can comfortably assume that the condition of workers is worse in Africa and in some other continents where democracy has not taken solid grounds.

The question then is how are church leaders performing in the context of Africa where leadership is much influenced by cultural values, traditional and political leaders who advocate being in power forever. The main issue is whether a church leader in the African context is influenced by his environment as he chooses his leadership styles or he succumbs to the temptation of being influenced by an environment which is full of a number of dictators (in some African Countries) who want to cling to power as long as they live by manipulating and maneuvering constitutions, causing their countries to go to civil war, prepare their children to replace them or even appoint them per force. No wonder that for four consecutive years, no outgoing African President has been able to win lbrahim prize of five million dollars.

Notwithstanding the above, very few African countries like Ghana, Botswana, Benin, Zambia, Malawi and Tanzania (just to mention a few) have been performing quiet well en route to democracy. Perhaps, church leaders in these zones would perform better than those in the rest of Africa. .

According to Stephen and Mary (2009), in today's uncertain environment, an important consideration for leaders is building trust and credibility. So, can we trust our church leaders? Can they stand the test of credibility? Can they make a difference? We have many church leaders who are dependable and trustworthy. The trustworthiness of every leader depends upon a number of factors such as how he comes to power, how he relates to the people under his authority what he does, how he does once in power and how he leaves power, among other things. Leaders are expected to come to power through legitimate means within the framework of the policies or constitutions. Once in power, leaders are expected to uphold to improving the livelihood of citizens practicing equity and fairness for all and make tangible marks in democracy, human rights, socio-economic and educational advancement. A church leader is expected to do more by exhibiting Christian values at high level and, since he is a messenger of God, adopt servant leadership style.

The premise being made here is that church leaders should set good examples to be shadowed by church members, communities, societies in general and political leaders in particular. The power of church leaders should not be transformed in a kind of corruption through fake miracles and prayers for a fee or counseling for a fee. It is generally accepted that a good work relationship is a strong contributing factor to good performance of the organizational objectives. A stressful working environment may cause employees to be depressed. Leaders are the ones to create and maintain positive work climate by establishing appropriate organization structure, good policies and their implementation. Their leadership styles also affect organizational performance and productivity.

There have been allegations that some men and women of God in church leadership positions do not do enough to create good work environment in the Adventist conferences, missions, hospital, schools and other church institutions. However, so far, nobody is able to know the extent of that alleged misbehavior and their causes. There are pastors or employees who seek personal transfer to other conferences (mission) because they are not comfortable to work in their respective home conferences in the country. Therefore, there is a need to undertake a research into the leadership styles adopted by church leaders. Thus, this research endeavors to study leadership styles of SDA (Seventh - day Adventist) church leaders of Ghana.

\section{REVIEW OF RELATED LITERATURE}

\section{The Concept of Leadership}

The word leadership has many meanings and interpretations. It is a complex process and there are serious reservations over the extent to which a set of standards, qualities or competencies can ever fully capture the nature of what makes some leaders successful and others unsuccessful. According to Cohen, Fink, Gadon, \& Wills (1995), a leader is a person who decides on what that work ought to be. This places the leader in a position of providing direction to be taken. Truman (1997) defines leadership as the ability to get people to do what they do not want to do. This is the character of the $21^{\text {st }}$ century worker (Cohen et al, 1995). Leadership therefore can be described as a process whereby an individual influences a group of individuals to achieve a common goal (Northouse, 2007). This means that leadership is a process by which a person influences others to accomplish an objective and directs the organization in a way that makes it more cohesive and coherent. According to Jago (1982), leaders thus carry out this process by applying their leadership knowledge and skills. This is called process leadership. He also noted that personal traits could influence our actions. This he termed trait leadership, in that it was once believed that leaders were born rather than made. 


\section{Leadership Behaviours and Processes}

Leadership is effective when followers have been successfully influenced by a leader to accomplish a shared inspirational goal. Certain behaviours of leaders determine the results of leadership. Leaders should be able to use behaviour patterns in an effective manner to positively influence followers.

According to Howell and Costley (2006), the following are core behaviour patterns of leaders:

$>$ Situational Leadership behaviour - this behaviour pattern refers to leader's role in showing concern for the comfort and well-being of followers; demonstrating a considerate, kind, and understanding attitude in dealing with followers; being friendly and informative, two-way communication and follower development. Familiar terms in this type of leadership are consideration, relationship orientation, and concern for people leadership.

$>$ Directive leadership behaviour - this pattern refers to the leader's behaviour in assigning followers to specific tasks explain methods to be used in completing the tasks, clarifying expectations, regarding quality and quantity of follower performance, setting goals for performance, setting goals for followers, planning and coordinating followers work, specifying rules and procedures to be followed. This behaviour pattern has also been known as or is closely related to initiating structure, instrumental leadership, or task oriented leadership.

> Participative leadership behaviour: sometimes referred to as delegatory, consultative, or democratic leadership. This behaviour involves leaders engaging followers in decision making. This leadership behaviour may include the following:

1. Holding one-on-one meetings with individuals or groups of followers to gather input for decisions.

2. A group decision-making effort initiated by the leader.

3. Assigning a particular problem to a follower to resolve.

Each of these options represents different types of participative leadership behavior:

$>$ Leader reward and punishment behaviour: with this leadership behaviour, the leader rewards followers who provide services with tangible or intangible benefits. The rewards may be monetary or praise. Reward or punishment may be provided based on followers' performance or leader's discretion.

$>$ Charismatic leadership behaviour: this pattern of leadership behaviour involves communication of a vision of the future that has an ideological significance to the followers, arousing followers' needs that are relevant to goal accomplishments, serving as a role model, expressing high expectations, and confidence in followers' capabilities and projecting a high degree of self-confidence.

Leaders use these patterns of behaviour to influence followers to accomplish group goals. A leader may demonstrate all patterns of behaviour or any subset of them with any group followers depending upon specific conditions

In addition to the above popular leadership styles, Robert Greenleaf (1970) advocated Servant Leadership. The concept servant leadership underscores the leader's responsibility to serve the follower. This writer describes servant leadership as follows:

"The servant-leader is servant first... It begins with the natural feeling that one wants to serve, to serve first. Then conscious choice brings one to aspire to lead. He or she is sharply different from the person who is leader first, perhaps because of the need to assuage an unusual power drive or to acquire material possessions. For such it will be a later choice to serve - after leadership is established. The leader-first and the servant-first are two extreme types. Between them there are shadings and blends that are part of the infinite variety of human nature.

The difference manifest itself in the care taken by the servant-first to make sure that other people's highest priority needs are being served. The best test, and difficult to administer, is: do those served grow as persons; do they, while being served, become healthier, wiser, freer, more autonomous, more likely themselves to become servants? And, what is the effect on the least privileged in society; will they benefit, or, at least, will they not be further deprived?" According to Green-leaf-Servant Leadership is a practical philosophy that supports people who choose to serve first, and then lead as a way of expanding service to individuals and institutions. Servant-leaders may or may not hold formal leadership positions. Servant-leadership encourages collaboration, trust, foresight, listening, the ethical use of power and empowerment.The emphasis on serving a higher purpose has made this model popular within the Church and other religious institutions.

Towards Leadership Effectiveness Leadership scholars have used many different indicators to measure leadership effectiveness. Indicators include: 
- Job performance and

- Group and organizational outcomes such as high productivity and profitability, market share, market growth, competitive position, union membership, group cohesion, church attendance, rates of employee turnover, absenteeism ( Howell and Costley, 2006).

\section{METHODOLOGY}

A descriptive survey was used to conduct the study. This design was used considering the nature of the study as a qualitative study. . It therefore considered the most appropriate design by virtue of the fact that the design is mostly used in situations of drawing inferences on opinion studies.

The target population for this research is made of all employees and officers in SDA Conferences and Mission, schools, hospitals, church districts and some selected workers from ADRA. All these institutions are located in Ghana as the research was narrowed down to the Ghanaian environment.For the sample of this study, two hundred and fifty employees were given a structured questionnaire. Convenience sampling technique was used as only respondents who were willing to respond were selected for the study.Questionnaire was used for the data collection as the research aims at finding out opinion of employees about the leadership styles and work relationships. The questionnaire is an appropriate instrument to collect data which affords us to make inferences or description of opinion on a subject matter. The data obtained from the questionnaire was analyzed by using tables, frequencies and percentages with the help of Microsoft Excel.

\section{FINDINGS AND ANALYSIS}

\section{DIRECTIVE LEADERSHIP STYLE}

\begin{tabular}{|c|c|c|c|c|c|c|}
\hline $\begin{array}{l}\text { CHARACTERISTICS } \\
\text { LEADERSHIP }\end{array}$ & SD & $\mathrm{D}$ & UD & A & SA & TOTAL \\
\hline Pastors and Leaders are Action Oriented & 2 & 0 & 25 & 17 & 27 & 71 \\
\hline $\begin{array}{l}\text { Church Leaders Are Reluctant To Leave Their } \\
\text { Positions }\end{array}$ & 1 & 12 & 3 & 49 & 6 & 71 \\
\hline Happy With Policies Implemented & 19 & 4 & 13 & 11 & 24 & 71 \\
\hline Officers Fight for Positions & 1 & 8 & 3 & 35 & 24 & 71 \\
\hline Leaders Adopt Confrontational Attitudes & 3 & 11 & 1 & 7 & 49 & 71 \\
\hline $\begin{array}{lllll}\text { Supervisor's Instructions and Listening to } \\
\text { Suggestions }\end{array}$ & 3 & 11 & 10 & 23 & 24 & 71 \\
\hline Administrators Have Domineering Attitudes & 0 & 3 & 0 & 41 & 27 & 71 \\
\hline Summary & 29 & 49 & 55 & 183 & 181 & 497 \\
\hline Percentages of Summary & 5.84 & 9.86 & 11.07 & 36.82 & 36.42 & 100 \\
\hline
\end{tabular}

The above table summary revealed that, respondents agreed that leaders exhibit directive leadership style in the SDA Church and its institutions. This was because, a cumulative percent of 73.24 of the respondents agreed and strongly agreed that their leaders were directive in leading.

\section{PARTICIPATIVE LEADERSHIP STYLE}

\begin{tabular}{|l|l|l|l|l|l|l|}
\hline $\begin{array}{l}\text { CHARACTERISTICS OF PARTICIPATIVE } \\
\text { LEADERSHIP SD }\end{array}$ & D & UD & A & SA & TOTAL \\
\hline Employees Participation In Decision Making & 2 & 3 & 15 & 31 & 20 & 71 \\
\hline Supervisor Takes Time To Listen To Me & & 11 & 3 & 33 & 24 & 71 \\
\hline $\begin{array}{l}\text { Employees Express Themselves Freely Without } \\
\text { Fear of Being Victimized }\end{array}$ & 0 & 20 & 27 & 12 & 12 & 71 \\
\hline Happy With Policies Implemented & 19 & 4 & 13 & 11 & 24 & 71 \\
\hline
\end{tabular}




\begin{tabular}{|l|l|l|l|l|l|l|}
\hline Effective Communication & 1 & 22 & & 43 & 5 & 71 \\
\hline Officers Comply with Work Policies & 0 & 2 & 2 & 38 & 29 & 71 \\
\hline Satisfaction Supervisors Relationships & 3 & 1 & & 22 & 45 & 71 \\
\hline Summary & $\mathbf{2 5}$ & $\mathbf{6 3}$ & $\mathbf{6 0}$ & $\mathbf{1 9 0}$ & $\mathbf{1 5 9}$ & $\mathbf{4 9 7}$ \\
\hline Percentages of Summary & $\mathbf{5 . 0 3}$ & $\mathbf{1 2 . 6 8}$ & $\mathbf{1 2 . 0 7}$ & $\mathbf{3 8 . 2 3}$ & $\mathbf{3 1 . 9 9}$ & $\mathbf{1 0 0}$ \\
\hline
\end{tabular}

Concerning the participative leadership style of leaders of the SDA Church and its institutions, it was found in the table above that, a cumulative percent of 70.22 of the respondents agreed that leaders of the SDA Church and the church's institutions show participative leadership style. However, a cumulative percent of 17.71 of the respondents disagreed that, leaders of the SDA Church and the church's institutions show participative leadership style.

\section{LEADERS REWARD/PUNISHMENT BEHAVIOR}

\begin{tabular}{|l|l|l|l|l|l|l|}
\hline LEADERS REWARD/PUNISHMENT BEHAVIOR & SD & D & UD & A & SA & TOTAL \\
\hline $\begin{array}{l}\text { Leaders Rebuke or Punish Bad Behaviors at the } \\
\text { Work Place Justly and Fairly }\end{array}$ & 3 & 2 & 1 & 55 & 10 & 71 \\
\hline Positive Impact from Leaders or Supervisors & 0 & 3 & 12 & 31 & 25 & 71 \\
\hline $\begin{array}{l}\text { Christian Values are Highly Experienced at the } \\
\text { Work Place }\end{array}$ & 0 & 1 & 6 & 21 & 13 & 41 \\
\hline Summary & $\mathbf{3}$ & $\mathbf{6}$ & $\mathbf{1 9}$ & $\mathbf{1 0 7}$ & $\mathbf{4 8}$ & $\mathbf{1 8 3}$ \\
\hline Percentages of Summary & $\mathbf{1 . 6 4}$ & $\mathbf{3 . 2 8}$ & $\mathbf{1 0 . 3 8}$ & $\mathbf{5 8 . 4 7}$ & $\mathbf{2 6 . 2 3}$ & $\mathbf{1 0 0}$ \\
\hline
\end{tabular}

The table above also show that, a cumulative percent of 84.70 of the respondents agreed that, leaders of the SDA Church and its institutions use leaders' reward/punishment behavior. On the other hand, 4.92 and 10.38 percent of the respondents disagreed and were undecided that leaders of the SDA Church and its institutions use leaders' reward/punishment behavior respectively.

\section{CHARISMATIC LEADERSHIP STYLE}

\begin{tabular}{|l|l|l|l|l|l|l|}
\hline $\begin{array}{l}\text { CHARACTERISTICS OF CHARISMATIC } \\
\text { LEADERSHIP }\end{array}$ & SD & D & UD & A & SA & TOTAL \\
\hline Effective Communication & 1 & 22 & 0 & 43 & 5 & 71 \\
\hline Officers Comply with Work Policies & 0 & 2 & 2 & 38 & 29 & 71 \\
\hline Blindly Attracted to Leaders & 20 & 3 & 4 & 18 & 26 & 71 \\
\hline $\begin{array}{l}\text { Christian Values are Highly Experienced at the } \\
\text { Work Place }\end{array}$ & 1 & 6 & 21 & 13 & 30 & 71 \\
\hline Church Leaders Are Visionaries & 1 & 3 & 10 & 43 & 14 & 71 \\
\hline Leaders Are Trust Worthy & 12 & 1 & 1 & 34 & 23 & 71 \\
\hline Summary & $\mathbf{3 5}$ & $\mathbf{3 7}$ & $\mathbf{3 8}$ & $\mathbf{1 8 9}$ & $\mathbf{1 2 7}$ & $\mathbf{4 2 6}$ \\
\hline Percentages of Summary & $\mathbf{8 . 2 2}$ & $\mathbf{8 . 6 9}$ & $\mathbf{8 . 9 2}$ & $\mathbf{4 4 . 3 7}$ & $\mathbf{2 9 . 8 1}$ & $\mathbf{1 0 0}$ \\
\hline
\end{tabular}

Further, the table above indicated that, leaders of the SDA Church and its institutions exhibit charismatic leadership style. This was because, a cumulative percent of 74.18 of the respondents agreed that their leaders employ charismatic leadership style. However, a cumulative percent 16.90 of the respondents disagreed and 8.92 were undecided that leaders used charismatic leadership style. 


\section{SUPPORTIVE LEADERSHIP STYLE}

\begin{tabular}{|l|l|l|l|l|l|l|}
\hline $\begin{array}{l}\text { CHARACTERISTICS OF SUPPORTIVE } \\
\text { LEADERSHIP SD }\end{array}$ & D & UD & A & SA & TOTAL \\
\hline Leaders Are Caring & 30 & 2 & 22 & 16 & 1 & 71 \\
\hline Supervisor Takes Time and Listens To Me & 0 & 11 & 3 & 33 & 24 & 71 \\
\hline Satisfaction Supervisors Relationships & 0 & 3 & 1 & 22 & 45 & 71 \\
\hline Create A Supportive Environment & 12 & 3 & 31 & 16 & 9 & 71 \\
\hline Summary & $\mathbf{4 2}$ & $\mathbf{1 9}$ & $\mathbf{5 7}$ & $\mathbf{8 7}$ & $\mathbf{7 9}$ & $\mathbf{2 8 4}$ \\
\hline Percentages of Summary & $\mathbf{1 4 . 7 9}$ & $\mathbf{6 . 6 9}$ & $\mathbf{2 0 . 0 7}$ & $\mathbf{3 0 . 6 3}$ & $\mathbf{2 7 . 8 2}$ & $\mathbf{1 0 0}$ \\
\hline
\end{tabular}

In looking at the supportive leadership style of the leaders of the SDA Church and its institutions, a cumulative percent of 58.45 of the respondents agreed that leaders of the SDA Church and its institutions exhibited supportive leadership style. But cumulative percent of 21.48 percent of the respondents disagreed that their leaders used supportive leadership style. In addition, 21.48 percent of the respondents disagreed and 20.07 were undecided concerning this leadership style.

\section{LAISSEZ FAIRE LEADERSHIP STYLE}

\begin{tabular}{|l|l|l|l|l|l|l|}
\hline CHARACTERISTICS OF LAISSEZ FAIRE LEADERSHIP & SD & D & UD & A & SA & TOTAL \\
\hline Respect Employees' Profession & 2 & 12 & 3 & 9 & 45 & 71 \\
\hline
\end{tabular}

Concerning laissez faire leadership style, 14 of the respondents disagreed that their leaders used laissez faire leadership style. But 54 of the respondents agreed that their leaders used laissez faire leadership style and 3 respondents were undecided.

\section{SERVANT LEADERSHIP STYLE}

\begin{tabular}{|l|l|l|l|l|l|l|}
\hline $\begin{array}{l}\text { CHARACTERISTICS OF SERVANT } \\
\text { LEADERSHIP }\end{array}$ & SD & D & UD & A & SA & TOTAL \\
\hline Leaders Are Caring & 30 & 2 & 22 & 16 & 1 & 71 \\
\hline Engages and Invites Opinions & 1 & 3 & 22 & 8 & 37 & 71 \\
\hline Summary & $\mathbf{3 1}$ & $\mathbf{5}$ & $\mathbf{4 4}$ & $\mathbf{2 4}$ & $\mathbf{3 8}$ & $\mathbf{1 4 2}$ \\
\hline Percentages of Summary & $\mathbf{2 1 . 8 3}$ & $\mathbf{3 . 5 2}$ & $\mathbf{3 0 . 9 9}$ & $\mathbf{1 6 . 9 0}$ & $\mathbf{2 6 . 7 6}$ & $\mathbf{1 0 0}$ \\
\hline
\end{tabular}

The table above also indicated that a cumulative percent of 43.66 of the respondents agreed that their leaders employed servant leadership style. On the other hand, a cumulative percent of 25.35 of the respondents disagreed that their leaders employed servant leadership style and 30.99 percent were undecided.

\section{SUMMARY OF FINDINGS}

\begin{tabular}{|l|l|l|l|l|l|l|}
\hline SUMMARY OF LEADERSHIP STYLE & SD & D & UD & A & SA & TOTAL \\
\hline Directive Leadership & 5.84 & 9.86 & 11.07 & 36.82 & 36.42 & 100 \\
\hline Participative Leadership & 5.03 & 12.68 & 12.07 & 38.23 & 31.99 & 100 \\
\hline Charismatic Leadership & 8.22 & 8.69 & 8.92 & 44.37 & 29.81 & 100 \\
\hline Supportive Leadership & 14.79 & 6.69 & 20.07 & 30.63 & 27.82 & 100 \\
\hline Servant Leadership & 21.83 & 3.52 & 30.99 & 16.90 & 26.76 & 100 \\
\hline Laissez Faire Leadership & 2.82 & 16.90 & 4.23 & 12.68 & 63.38 & 100 \\
\hline Leaders Reward/ Punishment Behavior & 1.64 & 3.28 & 10.38 & 58.47 & 26.23 & 100 \\
\hline
\end{tabular}


The table above revealed that, a cumulative percent of 84.70 of the respondents agreed that leaders in the church and church institutions exhibit leaders' reward/punishment than all the other type of leadership styles. This was followed by laissez faire leadership style with a cumulative percent of 76.06 of the respondents agreeing to that fact. Charismatic, directive and participative leadership styles follow in downward succession. Supportive and servant leadership styles happened to be the least leadership styles exhibited by leaders of the SDA Church and its institutions. Thus, all leaders of the SDA Church employ all the leadership styles but they make use more of some of the leadership styles than others.

\section{WORK RELATIONSHIP IN SDA CHURCH INSTITUTIONS}

\begin{tabular}{|l|l|l|l|l|l|l|}
\hline $\begin{array}{l}\text { WORK RELATIONSHIP IN CHURCH } \\
\text { INSTITUTIONS }\end{array}$ & SD & D & UD & A & SA & TOTAL \\
\hline Happy With Policies Implemented & 19 & 4 & 13 & 11 & 24 & 71 \\
\hline Leaders Adopt Confrontational Attitudes & 3 & 11 & 1 & 7 & 49 & 71 \\
\hline Employees Participate In Decision Making & 2 & 3 & 15 & 31 & 20 & 71 \\
\hline $\begin{array}{l}\text { Employees Express Themselves Freely Without } \\
\text { Fear of Being Victimized }\end{array}$ & 0 & 20 & 27 & 12 & 12 & 71 \\
\hline Effective Communication & 1 & 22 & 0 & 43 & 5 & 71 \\
\hline $\begin{array}{l}\text { Leaders Rebuke or Punish Bad Behaviors at the } \\
\text { Work Place Justly and Fairly }\end{array}$ & 3 & 2 & 1 & 55 & 10 & 71 \\
\hline Leaders Are Caring & 30 & 2 & 22 & 16 & 1 & 71 \\
\hline Supervisor Takes Time and Listens To Me & 0 & 11 & 3 & 33 & 24 & 71 \\
\hline Engages and Invites Opinions & 1 & 3 & $\mathbf{2 2}$ & $\mathbf{8}$ & $\mathbf{3 7}$ & 71 \\
\hline Summary & $\mathbf{5 9}$ & $\mathbf{7 8}$ & $\mathbf{1 0 4}$ & $\mathbf{2 1 6}$ & $\mathbf{1 8 2}$ & $\mathbf{6 3 9}$ \\
\hline Percentages of Summary & $\mathbf{9 . 2 3}$ & $\mathbf{1 2 . 2 1}$ & $\mathbf{1 6 . 2 8}$ & $\mathbf{3 3 . 8 0}$ & $\mathbf{2 8 . 4 8}$ & $\mathbf{1 0 0 . 0 0}$ \\
\hline
\end{tabular}

It can be recognized from the table above that, a cumulative percent of 62.28 of the respondents agreed that their leaders have good work relationship with them. However, 21.44 percent disagreed and 16.28 were undecided. But within the table above, it was revealed that 56 of the respondents agreed that leaders adopt confrontational attitudes in dealing with them while 23 respondents disagreed. It was also identified that 65 respondents agreed that their leaders rebuke or punish bad behavior at the work place justly and fairly. Furthermore, 51 respondents agreed that they participate in decision making and 57 respondents agreed that their supervisors take time and listen to them. However, it is quite puzzling that 32 of the respondents disagreed that their leaders are caring and 20 disagreed that they can express their opinions freely without fear of victimization.

\section{CONCLUSION}

Based on the research findings, it is concluded that the officers in SDA Conferences, mission, schools, hospitals and churches demonstrate or use reward/punishment strategies to influence subordinates than all the other leadership styles. This was followed by laissez faire leadership style. Charismatic, directive and participative leadership styles follow in downward succession. Supportive and servant leadership styles happened to be the least used leadership styles exhibited by leaders of SDA Church and its institutions. A cumulative percent of 62.28 of the respondents agreed that their leaders have good work relationship with them. It was also discovered that their leaders rebuke or punish bad behavior at the work place justly and fairly.

\section{RECOMMENDATIONS}

The analysis above indicates that, SDA church leaders exhibit (depending on circumstances) all leadership styles such as directive, participative, reward and punishment, laissez-faire, servant, and charismatic leadership styles. However, they scored low on servant leadership and work relations. In addition they scored high regarding domineering attitude and cleaving to power (table 1). They definitely need to improve in these last four areas. 
It is recommended that, the Seventh-day Adventist Church Leaders practice more of servant leadership style and improve their work relations.

In addition, some leaders need to reduce domineering attitude and cleaving to power when their terms are due, as this produces an unattractive working environment for employees.

Annual workshops should be organized for the SDA pastors and others in leadership positions to sharpen their managerial and leadership skills.

Performance appraisal should be instituted in the SDA churches and institutions on leaders. This would help leaders to assess and improve their performances.

Counseling, communication skills and psychology should be inculcated in the syllabus of SDA Pastors. Alternatively, short courses should be organized for them in these areas.

\section{REFERENCES}

Cohen et al, (1995).Leadership and expectations: Pygmalion effects. Leadership Quarterly, 3, 278-279.

Cohen, Fink, Gadon, \& Wills (1995).). Relationship-based approach to leadership: Development of the leadermember exchange (LMX) theory of leadership over 25 years. Leadership Quarterly, 6, 219-247.

Dansereau, F., Graen, G., \&Haga, W. J. (1975) "A vertical dyad approach to leadership within formal organizations", Organizational Behavior and Human Performance, 12: 46-78.

Drucker.P. (1985). What the World's Greatest Management Thinker Means to Today's Business Leaders, published by McGraw-Hill

Greenleaf, R. K. (1970). Leadership with easy Answers.http://www.wabash.edu/news/6606

Jago, A. G. (1982). Leadership: Perspectives in theory and research. Management Science, 28(3)

Northouse, G. (2007). Leadership theory and practice, $3^{\text {rd }}$ ed. Thousand Oak. London. New Delhe, Sage Publications, Inc

Tannenbaum, R. and Schmidt, W. (1958) How to choose a leadership pattern. Harvard Business Review 36(2), 95101

Truman, K. G. (1997). Management and Leadership Abilities: An analysis of texts, testimony and practice. London: Council for Excellence in Management and Leadership. Online at: :

http://www.managementandleadershipcouncil.org/reports/r30.htm.

http://negocios.udd.cl/gemchile/files/2011/01/fulltext.pdf

http://www.brookings.edu/ /media/research/files/papers/2011/8/entrepreneurship\%20younis\%20younis/08_entrepren eurship_younis_younis.pdf

http://www.hks.harvard.edu/m-rcbg/CSRI/publications/report_41_corporate_entrepreneurship.pdf

http://stvp.stanford.edu/documents/about/presentations/Building_an_E-ship_Program.pdf

http://eur-lex.europa.eu/LexUriServ/LexUriServ.do?uri=COM:2012:0795:FIN:en:PDF

http://web.ebscohost.com/ehost/pdfviewer/pdfviewer?sid=08f8c612-9263-4e60-a1d3-

73a971 a358fa\%40sessionmgr 12\&vid=1\&hid=11 